\title{
Psikolojik Yıldırma İle İşten Ayrılma Niyeti Arasındaki İlişkide Örgütsel Sinizmin Aracılık Etkisi (Mediating Effect of Organizational Cynicism on the Relationship Between Mobbing and Intention to Leave)
}

\section{Halime GÖKTAŞ KULUALP iD a}

a Karabük Üniversitesi, Safranbolu Turizm Fakültesi, Karabük, Türkiye. halimegoktas@karabuk.edu.tr

\begin{tabular}{|c|c|}
\hline MAKALE BİLGİSİ & ÖZET \\
\hline $\begin{array}{l}\text { Anahtar Kelimeler: } \\
\text { Psikolojik Yıldırma } \\
\text { Örgütsel Sinizm } \\
\text { İşten Ayrılma Niyeti } \\
\text { Otel Çalışanları }\end{array}$ & $\begin{array}{l}\text { Amaç - Çağımızın mücadeleci rekabet ortamında işletmelerin ayakta kalmasını sağlayacak olan unsur } \\
\text { "insan-çalışan” faktörünün verimliliğidir. İşletme yönetimlerinin çalışandan verim beklemesi için çalışa- } \\
\text { nın işine karşı olumlu tutumlara sahip olmasını sağlaması çok önemlidir. İşe karşı olumsuz tutumların } \\
\text { örgüte, motivasyon düşüklüğü, örgütsel bağlllıkta ve işe devam oranında azalma, yabancılaşma, düşük } \\
\text { performans ve verimlilik ve örgütsel sinizm gibi pek çok olumsuz yansımaları olacaktır. Bu nedenle, işe } \\
\text { yönelik olumsuz tutumlara odaklanan bu çalışmada, psikolojik yıldırma ile işten ayrılma niyeti ilişkisinde } \\
\text { örgütsel sinizmin aracılık etkisi incelenmiştir. }\end{array}$ \\
\hline $\begin{array}{l}2019 \\
\text { Revizyon Tarihi } 28 \text { Kasım } \\
2019 \\
\text { Kabul Tarihi } 6 \text { Aralık } 2019\end{array}$ & $\begin{array}{l}\text { Yöntem - İkincil kaynaklardan veriler toplanarak literatür taraması yapılmıştır. Araştırma kapsamında, } \\
\text { Ankara'da çalışan } 267 \text { otel çalışanına anket uygulanmıştır. Elde edilen veriler üzerinde frekans analizi, } \\
\text { güvenirlik analizi, korelasyon analizi, açıklayıcı faktör analizi ve regresyon analizi kullanılmıştır ve so- } \\
\text { nuçta kurulan } 3 \text { hipotez kabul edilmiştir. }\end{array}$ \\
\hline $\begin{array}{l}\text { Makale Kategorisi: } \\
\text { Araştırma Makalesi }\end{array}$ & $\begin{array}{l}\text { Bulgular - Yapılan analiz sonuçlarına göre, psikolojik yıldırma algısı ile örgütsel sinizm ve işten ayrılma } \\
\text { niyeti arasında yüksek düzeyde korelasyon ilişkisi olduğu tespit edilmiştir. Analiz bulgularna göre, psi- } \\
\text { kolojik yıldırma ile örgütsel sinizm arasında ve psikolojik yıldırma ile işten ayrılma niyeti arasında pozitif } \\
\text { yönlü ve anlamlı bir ilişki tespit edilmiştir. Ayrıca, temel araştırma hipotezine göre, psikolojik yıldırma } \\
\text { ile işten ayrılma niyeti arasındaki ilişkide örgütsel sinizmin aracılık etkisinin olduğu kabul edilmiştir. }\end{array}$ \\
\hline & $\begin{array}{l}\text { Tartışma - Elde edilen en önemli çıktı, psikolojik yıldırma, örgütsel sinizm ve işten ayrılma niyeti arasın- } \\
\text { daki ilişkinin istatistiki olarak anlamlı olmasıdır. Önemli bir diğer sonuç ise, psikolojik yıldırma içerisinde } \\
\text { olan bir çalışanın işten ayrılma niyetinin yüksek olacağı eğer bu çalışanın örgütsel sinizm tutumu da varsa } \\
\text { işten ayrılma niyetinin daha da yüksek olacağıdır. Dolayısıyla, bu olumsuz iş tutumlarına karşı önlem } \\
\text { alınmalıdır. }\end{array}$ \\
\hline
\end{tabular}

\begin{tabular}{l}
\hline ARTICLE INFO \\
\hline Keywords: \\
Mobbing \\
Organizational Cynicism \\
Intention to Leave \\
Hotel Staff
\end{tabular}

Received 8 September 2019

Revised 28 November 2019

Accepted 6 December 2019

ABSTRACT

Article Classification:

Research Article

Purpose - The survival of enterprises depends on the efficiency of the human-employee factor in the competitive environment of our age. It is very important that the management manages to have positive attitudes towards the work of the employee in order to get the employee more efficient. Negative attitudes towards work will have many negative effects on the organization, such as reduced motivation, organizational commitment and reduction in work attendance, alienation, low performance and productivity and organizational cynicism. Therefore, the mediating effect of organizational cynicism on the relationship between mobbing and intention to leave is determined in this study which focuses on negative attitudes towards work.

Design/methodology/approach - Data were collected from secondary sources and literature review was performed. Within the scope of the research, 267 hotel employees in Ankara were surveyed. Frequency analysis, reliability analysis, correlation analysis, explanatory factor analysis and regression analysis were used on the obtained data. As a result, three hypotheses were accepted.

Findings - According to the results of the analysis, a high correlation was found between mobbing, organizational cynicism and intention to leave. According to the findings of the analysis, a positive and significant relationship was found between mobbing and organizational cynicism and between mobbing and intention to leave. In addition, according to the basic research hypothesis, it is accepted that organizational cynicism has a mediating effect on the relationship between mobbing and intention to leave.

Discussion - The most important outcome is that the relationship between mobbing, organizational cyncism and intention to leave is statistically significant. Another important result is that an employee who is in mobbing will have a high intention to leave. In this relationship, if the employee has an attitude of organizational cynicism, his intention to leave will be even higher. Therefore, measures should be taken against these negative business attitudes. 


\section{Giriş}

Bir örgüt içerisinde yer alan çalışanlar belirli amaçları gerçekleştirmek üzere bir arada bulunurlar. Birey, kendisini mutlu ve rahat hissettiği çalışma ortamında daha verimli çalışarak örgüt amaçlarına daha hızlı ve kolay bir şekilde ulaşılmasına yardımcı olur. Eğer, birey kendisini bulunduğu ortamda iyi hissetmiyorsa başka bir ifadeyle işinden memnun değilse bu durum kişide olumsuz iş tutum ve davranışlarının oluşmasına sebep olabilir. Kaymakcı (2008)'e göre, iş hayatında yıldırmaya maruz kalmış kişiler depresyon, öfke, kaygı ve stres gibi duygulara sahip olabilirler. Bu davranışı körükleyen başlıca nedenler yetersizlik duygusu, rekabet, kıskançlık, güçlü olduğunu ispat etme isteği ve saldırgan davranış eğilimleridir.

Çalışma hayatında sıkça kullanılan psikolojik yıldırma kavramı, çalışanın iş ortamında huzursuz edilmesi, bezdirilmesi (TDK, 2019) anlamına karşılık gelmektedir. Psikolojik yıldırmanın uygulandığı yerlerde rahat ve verimli çalışma ortamı da bozulmaya başlayacaktır. Bu durum, güven duygusunu da sekteye uğratabilir ve grup çalışmalarında aksaklıkların oluşmasına neden olabilir. Psikolojik yıldırma, iş yerinde bir grubun, diğer gruba veya bir kişiye sistematik bir şekilde uyguladığı aşağılayıcı, bezdirici, haksız söz ve davranışlardır. Bezdirme amacı olduğu için herhangi bir sınırı da yoktur. Psikolojik yıldırma birçok ülkede çeşitli sektörlerde yaşanmasına rağmen fazla üzerine düşülmemekte ya da görmezden gelinmektedir. Bunlara sebep olan nedenlerin başında tanı konulmasının oldukça zor olması gelmektedir. Psikolojik yıldırmanın uygulayıcıları ve mağdurları bu süreçten çıkmakta oldukça zorlanmaktadırlar.

Özellikle günümüzde sık görülen psikolojik yıldırma hareket ya da söylemleri gerek çalışanı gerekse çalışılan kurumu çok ciddi sorunlarla karşı karşıya bırakabilmektedir. Psikolojik yıldırma en fazla iş hayatında karşımıza çıkmaktadır. Bir kişiyi ya da grubu hedef alan psikolojik yıldırma, şiddete, sistematik baskıya, dedikodulara, sözlü ve fiziki saldırılara sebep olmakta ve bu nedenle mağdurların hayatlarına, sosyal statülerine ve düşüncelerine ciddi zararlar vermektedir. Gerek işletmenin ismine ve gerekse çalışanlar arası ilişkilere bu şekilde büyük zararlar veren psikolojik yıldırmanın nedenlerinin araştırılması ve önlemler alınması işletmenin geleceği için önem taşımaktadır. Psikolojik yıldırmaya maruz kalan çalışanların işten ayrılma eğiliminde oldukları yapılan çalışmalar (Jackson ve Maslach, 1982; Cordes ve Dougherty, 1993; Akbolat, Yılmazer ve Tutar, 2014) tarafından kanıtlanmıştır. Yöneticilerin çalışanlarını kaybetmemek için çalışanların sahip oldukları olumsuz iş tutumlarını azaltmaya yönelik tedbirler almaları çok önemlidir.

Kişinin iş ortamında kendisini mutsuz hissetmesine neden olacak bir kavram olan psikolojik yıldırma konusuna odaklanan bu çalışmada psikolojik yıldırmanın yanısıra olumsuz iş tutum ve davranışlarından olan örgütsel sinizm ve işten ayrılma niyeti konularına da değinilmiştir. Literatürde psikolojik yıldırma ile örgütsel sinizm ilişkisini inceleyen çalışmalar (Bedük vd., 2017; Kalay vd., 2014; Aslan ve Akarçay, 2013; Ayduğan, 2012; Gül ve Ağıröz, 2011; Izquierdo, Esteban, Garcga-Izqugerdo ve Hernandez, 2006; Balducci vd., 2009) olduğu gibi psikolojik yıldırma ile işten ayrılma niyeti arasındaki ilişkiyi inceleyen çalışmalarda (Jackson \& Maslach, 1982; Rusbult, Farrell, Rogers ve Mainous, 1988; Rayner ve Cooper, 1997; Cordes ve Dougherty, 1993; Zapf ve Gross, 2001; Tinaz, 2006; Akbolat, Yılmazer ve Tutar, 2014; Aylan ve Koç, 2016) bulunmaktadır. Ancak, örgütsel sinizmin psikolojik yıldırma ve işten ayrılma niyeti ilişkisinde aracılık etkisini araştıran çalışma (Tilki, 2017) sayısı çok sınırlıdır. Bu anlamda, literatüre katkı sağlanması amaçlanmaktadır. Bu amaçla, işle ilgili olumsuz bir durumu ifade eden psikolojik yıldırma ile işten ayrılma niyeti ilişkisinde örgütsel sinizmin aracılık etkisi belirlenmiş ve olumsuz iş tutumlarının zararları üzerinde durularak işletme yöneticilerine olumsuz iş tutumlarını önlemeleri yönünde önerilerde bulunulmuştur.

\section{Kuramsal Çerçeve}

\subsection{Psikolojik Yıldırma}

Latince'de kararsız kalabalı anlamına gelen psikolojik yıldırma kelimesi, ortalıkta toplanmak, saldırmak ve rahatsız etmek anlamında kullanılmıştır (Çalak, 2017:3). Bir çalışanı iş arkadaşlarının, üst düzey yöneticilerinin, astlarının, hatta müşterilerinin sistematik olarak taciz ettikleri veya rahatsız ettikleri durumların araştırılmasında farklı terimler ve kavramlar kullanılmıştır (Einarsen, 2000); psikolojik terör (Leymann, 1996), sağhl̆ğ tehdit eden liderlik (Kile, 1990), işin kötüye kullanımı (Bassmann, 1992'den Akt. Rehman vd., 2015) ve mağduriyet (Olweus, 1994) bu terimlerden bazılarıdır. Yerli literatürde ise, psikolojik yıldırma terimi daha çok işyeri zorbalığı (Serçeoğlu vd., 2016), yıldırma, psikolojik şiddet (Aslan ve Akarçay, 2013) ve psikolojik (duygusal) taciz (Palaz, vd., 2008) şeklinde kullanılmıştır. Başka bir bakış açısıyla, Norveç, Japonya ve Anglosakson ülkeleri de 
İngiliz ve Avustralyalı araştırmacılar gibi psikolojik yıldırma terimi yerine bullying'i tercih ederken Amerika' da bullying'in okul örgütlerinde, psikolojik yıldırmanın ise iş yerlerinde kullanılması uygun görülmektedir (Pelit ve Kılıç, 2012: 123).

Lorenz, hayvanların grup içindeki davranışlarını açıklamak için psikolojik yıldırma kavramını kullanmış ve küçük bir hayvan grubunun daha büyük ve yalnız olan bir hayvandan gelebilecek tehlikeye karşı saldırgan davranışlarda bulunmalarını "psikolojik yıldırma" olarak nitelendirmiştir (Leymann, 1996:167). İş ortamındaki psikolojik yıldırma davranışını ise ilk olarak 1980 yılında Leymann açıklamıştır. Leyman'ın tanımına göre psikolojik yıldırma, işgörenlerin birbirlerini taciz etmek, huzursuz ve rahatsız etmek, kötü davranmak suretiyle birbirlerine psikolojik şiddet göstermeleridir (Tutar, 2004:103). Bazı özelliklerinden dolayı, psikolojik yıldırma davranışı, kişiler arasında gerçekleşen çatışmdan farklılık göstermektedir. İkisi arasındaki en önemli farklılık ne yapıldığı ya da nasıl yapıldığı ile ilgili değil, yapılan davranışın sıklığı (yoğunluğu) ve süresi ile ilgili (Zapf ve Einarsen, 2005) olmasıdır. Bir davranışın psikolojik yıldırma olarak nitelenmesi için, uzun bir zaman diliminde örneğin altı ay süresince haftada en azından bir kez çok yoğun şekilde devam etmesi gerekmektedir (Leymann, 1996:168).

Psikolojik yıldırmayı, zorbalık (bullying) olarak ifade eden Adams'a göre (1992), psikolojik yıldırma, bir kişiyi küçük düşüren ve küçümseyen kamu ya da özel sektörde yapılan kalıcı eleştiri ve kişisel tacizdir. Bu kelime, İskandinavya'da bir çalışana ya da yöneticiye karşı iş arkadaşlarınca, astları veya üstleri tarafından sistemli bir şekilde tekrar tekrar devam ederek belirli bir süre uygulanan ve küçük düşürücü, kötü ve düşmanca, hedef olarak görülen kişinin çalışma arzusunu, isteğini ve iş performansını geriletmeye yönelik hareketler şeklinde tanımlanmaktadır (Çilingir, 2015:3). Karşı tarafa psikolojik yıldırma uygulayanlar genelde övgüye ihtiyaç duyan, ilgiye muhtaç, bireysel yetersizlikleri bulunan, benlik egolarını tatmin etmek ve eksikliklerini telafi etmek için psikolojik şiddet yapanlardır (Davenport, Schwartz ve Elliott 2003). Bu tarz insanlar, kendilerini rahatlatmak ve iç benliklerini tatmin etmek için psikolojik yıldırma davranışında bulunurlar.

Leymann'a göre (1996), psikolojik yıldırma (yıldırma) beş boyuttan oluşan bir süreçtir ve bu boyutları ise 45 farklı yıldırma davranışı ile açıklamıştır. Leymann bu beş aşamayı “Leymann Psikolojik Terör Envanteri (Leymann Inventory of Psychological Terrorisation)" olarak tanımlamıştır (Çelik, 2009: 13). Leymann'ın (1996), beş boyutlu psikolojik yıldırma davranış şekilleri aşağıdaki gibidir:

Kendini Gösterme ve İletişim Oluşumuna Yönelik Saldırılar: Mağdur sürekli olumsuz yönde eleştirilere maruz kalarak aşağılanarak iş arkadaşları ve yöneticileri tarafından soyutlanarak yalnız bırakılmak istenir. Soyutlama şekli kendini gösterme ve iletişim oluşumuna yönelik saldırıların içerisinde yer alan adımlardan oluşmaktadır. Bu adımlar şu şekilde gerçekleşir; mağdurun sürekli sözü kesilir, üstleri tarafından azarlanır, yaptığı iş ve özel hayatı eleştirilir, kendini gösterme ve ifade etme fırsatı verilmez, mağdurun sözlerine inanılmaz, telefonla, mektupla ve sözlü olarak tehdit edilir, çalışma ortamında fikirleri önemsenmez (Ayduğan, 2012).

Sosyal İlişkilere Saldırı: Yöneticiler ve iş arkadaşları mağdurla konuşmayarak iletişim kurmaktan kaçınırlar. Ortamdan uzakta bir oda verilerek mağdurun duygusal ve fiziksel olarak negatif yönde etkilenmesini isterler. Ortamda mağdur yokmuş gibi davranılarak yıldırma politikası uygulanır (Çelik, 2009: 13).

Kişilerin İtibarına Saldırı: Mağdur komik durumlara düşürülmek istenerek gerçeği olmayan eleştirilere hedef olur. Yıldırma politikası uygulanan birey üzerinde psikolojik rahatsızlığı varmış olgusu yaratılmaya çalışılır. Jest ve mimikleriyle dalga geçilerek özgüven eksikliği yaratılmaya çalışılır. Mağdurun siyasi ve dini görüşleri ve özel yaşantısı alay konusu olur. Mağdurun insanların gözündeki saygınlık olgusunun yitirilmesi istenir (Çalak, 2017: 21).

Yaşam ve İş Kalitesine Saldırı: Mağdura yeteneklerinden daha düşük görevler verilerek, mağdurun anlamsız görevlerde zaman geçirmesini sağlayarak, kariyerinin olumsuz etkilenmesi ve gözden düşmesi konusunda her oyun oynanabilir. İşi sürekli değiştirilir, verilen işler geri alınarak görev yetki sınırları kısıtlanır ve mağdurun strese girmesi sağlanır, öz saygısını yitirecek görevler verilerek oluşan zararın sonucunu mağdura faturalandırılıp evine ve iş yerine hasar verilir (Çelik, 2009: 14).

Kişinin Sağhlğına Doğrudan Saldırı: Psikolojik yıldırma mağduruna fiziksel olarak zarar verici işlerin verilmesi, cinsel istismara uğraması, ağır işler yapmaya zorlanması gibi davranışlardır (Kalay, Oğrak ve Nişancı, 2014). 
Shallcross'a göre (2003), bir işyerinde gerçekleşen olayları psikolojik yıldırma olarak ifade edebilmek için o ortamda, bireysel ve örgütsel malzemelerin kaybolması ve uzun süre bulunamaması, yanlış ve kötüye kullanılan liderlik ve yönetim uygulamaları, merkeziyetçi ve hiyerarşik yapı, çatışma yönetiminin olmaması, küçük düşürücü, kötü niyetli, yıldırıcı davranışlarda bulunulması, birey hakkında asılsız yanlış bilgi içeren dedikodu söylemlerinin çıkarılması, mağdurun iş yapma şeklinde kötü niyetli bir şekilde kasıtlı olarak açıklık aranması, mağdurun yazılı ya da sözlü hiçbir talebinin dikkate alınmaması, görmezlikten gelme, sebepsiz kışkırtmaların yaşanması, ortak işyeri etkinliklerine mağdurun davet edilmemesi, dış görünüşü ya da konuşmasıyla dalga geçilmesi, sunduğu öneri ya da projelerin sürekli geri çevrilmesi, eşit düzeydeki iş arkadaşlarından düşük ücretlendirme yapılması gerekir.

Psikolojik yıldırma genel olarak iki şekilde uygulanır. Bunlar dikey veya yatay olmak üzere ikiye ayrılır.

Hiyerarşik (Dikey) Yıldırma: Örgütsel yapıya bağlı kalınarak, aşağıdan yukarıya veya yukarıdan aşağıya doğru hiyerarşik biçimde gerçekleşen psikolojik yıldırma biçimidir (Akça, 2014: 15). Psikolojik yıldırmanın çevrede en sık rastlanan formu üstler tarafından astlara uygulanan psikolojik yıldırma davranışlarıdır. Yukarıdan aşağıya doğru psikolojik yıldırma, her türlü sebepten dolayı bir üstten ya da bir amirden kaynaklı mağdura yönelik, cezalandırıcı, aksi, öfkeli, son derece saldırgan şekilde yapılan hareketlerdir. Amirin ya da yöneticinin bulunduğu pozisyondan yararlanması ve güç kullanmasıyla astlarına uyguladığı yıldırma davranışıdır. İspanya' da turizm sektöründe yapılan bir araştırmada katılımcıların \%45'inin psikolojik yıldırmaya maruz kaldıklarını ve bu durumun \%82'lik bir oranla patron veya üstlerinden ancak \%16'llk bir kısmının iş arkadaşlarında kaynaklandığı ortaya konulmuştur (Ayduğan, 2012: 35).

Yatay (Fonksiyonel) Yıldırma: Yatay psikolojik şiddetin başlıca nedenleri; hoşlanmama, çekememezlik, kıskançlık, rekabet, rrk ve politik nedenler olarak sıralanabilir. Yatay psikolojik şiddetin meydana geldiği zamanlarda örgüt yönetiminin taraflı olması psikolojik şiddetin zamanla örgüt politikası haline gelmesine neden olabilir. Bu durum karşısında psikolojik şiddetin etkisinde kalan kişi, yönetimdekiler ve üstlerin gücüyle de savaşmak durumda kalabilir. Yaşanan bu durumun ardından mağdur, örgüte karşı hem yalıtılmışlık hissine kapılabilir hem de örgütsel sürece yabancılaşabilir (Yapıcı, 2014: 17).

Özetle, astların üstlerine veya üstlerin astlarına uyguladıkları yıldırma kavramı dikey veya hiyerarşik psikolojik yıldırma olarak, aynı konumdaki kişilerin ya da kurmay-fonksiyonel ilişkisi içinde eşit bireylerin birbirine uyguladıkları psikolojik yıldırma ise yatay veya fonksiyonel psikolojik yıldırma olarak tanımlanmaktadır (Davenport vd., 2003).

Yatay şiddet gösterenler, mağdurun iyiliğini düşündüklerini, aslında şiddet uygulamadıklarını, uyarı amaçlı yaptıklarını ifade ederler. Onlar bu durumu, örgütsel verimliliği artırmak için yaptıklarını söyleyerek psikolojik yıldırmayı haklı bir gerekçeye bağlarlar (Akça, 2014: 17).

Psikolojik yıldırmaya uğrayan işgörenlerin örgütsel bağlılıkları ve sadakatleri azalır. Çalışan devir hızı yükselir. Tepe yönetimin saygınlığı kaybolur. Örgütsel hiyerarşide emir-komuta ilişkileri işlemez hale gelir ve koordinasyon sorunu baş gösterir. Psikolojik yıldırma sebebiyle işgörenler sıkça çalışma ortamından uzaklaşma ihtiyacı duyar ve stres kaynaklı sağlık sorunlarından dolayı tedavi giderleri artar, çalışan verimi düşer ve işyerinde gerilimli bir iklim meydana gelir (Tutar, 2004:114).

\section{2. Örgütsel Sinizm}

Örgütsel sinizm, kurumun dürüstlükten yoksun olduğu inancından yola çıkarak, bireyin hayal kırıklığı ve umutsuzluğa dayalı olarak kurumuna karşı olumsuz bir tutum sergilemesidir (Andersson ve Bateman, 1997; Dean, Brandes, ve Dhwardkar, 1998). Sinizm yaşayan bireyler, çalıştığı kurumun işletme değerlerini, faaliyetlerini ve motive edici özelliklerini eleştirel bir şekilde değerlendirerek örgütün bir kısmı ya da tamamına yönelik bir tutum belirler (Naus, Iterson ve Roe, 2007; Bedeian, 2007).

Sinizm kavramı çalışma ortamında iki farklı şekilde ele alınabilir (Tokgöz ve Yılmaz, 2008). Bu görüşlerden birincisi, sinizmin kişinin kendi kişilik özelliğinden kaynaklanan bulunduğu ortama karşı şüpheci, karamsar ve güvensiz bir tutum içerisinde olmasıdır ve bu kavram "genel sinizm" olarak ifade edilebilir (Abraham, 2000). İkinci görüş ise, "örgütsel sinizm” olarak isimlendirilen, bireyin görev yaptığı örgüte ilişkin geliştirdiği duygusal, bilişsel ve davranışsal tutum boyutlarını içerisinde barındıran olumsuz yönde bir tutumdur (Dean vd., 1998). 
Dean ve diğerlerine (1998) göre; örgütsel sinizm, bilişsel (cognitive), duyuşsal (affective) ve davranışsal (behavioural) olarak üç boyutta incelenir: Bilişsel boyuta göre; işletmeler dürüstlükten yoksundur. Bu nedenle, tüm faaliyetler dürüstlük, adalet, eşitlik kavramından uzak bir şekilde gerçekleştirilir. Tek amaç örgütsel amaçlara ulaşmaktır; bundan dolayı, amaçlara ulaşmak için tüm ilkeler kurban edilir. Örgütteki herkesin güvenilmez ve tutarsız davrandığına inanılır (Kalağan, 2009; Dean vd., 1998). Duyuşsal boyut: Bu boyuta göre; sinik tutumlar sergileyen çalışanlar sadece örgütüne karşı bazı duygulara sahip olan kişiler değil, ayı zamanda örgütleri içerisinde duygularla yaşayan varlıklar olarak görülmelidir (Dean vd., 1998). Ancak, bu duygular olumsuz olduğu için birey örgütüne karşı utanç ve tiksinme duyabilmektedir (Brandes vd., 1999). Duyuşsal sinizm, daha çok çalışanın sahip olduğu endişe, öfke, gerilim, saygısızlık, kızgınlık, utanma ve küçük görülme gibi duygularla ilgilenir (Abraham, 2000). Davranışsal Boyut: Duyuşsal boyuta göre çalışanın örgütüne karşı sahip olduğu olumsuz duygular neticesinde birey örgütünden şikayetçi olma, alay etme, eleştirel bakma gibi davranışlar gösterir (Dean vd., 1998).

Genel anlamda, bilişsel boyut, örgütsel samimiyet ve bütünlüğün bilinç düzeyinde değerlendirilmesini, duyuşsal boyut, negatif yönlü temel insan duygularını ve davranışsal boyut ise eleştirel ve küçümseyici davranışların örgütsel sinizm boyutunda incelenmesini ele almaktadır (Fitzgerald, 2002:19).

Çalışanda sinizme neden olan örgütsel nedenler arasında çalışanın adaletsizlik algısı gelmektedir (Fitzgerald, 2002). Anderson ve Bateman (1997) ise örgüt içerisinde ödül dağıtımı konusundaki negatif düşüncelerin yine sinizme neden olacağını savunmaktadır. Çalışan sinizmine neden olan bir diğer önemli faktör ise psikolojik sözleşme ihlalleridir. Yöneticilerin işin başlangıcında çalışana taahhüt ettiği konulara uygun davranmaması çalışanın işine karşı olumsuz duygular beslemesine sebep olacaktır (Morrison ve Robinson, 1997; Anderson ve Bateman, 1997; Abraham, 2000).

Örgütsel sinizmin doğuracağı olumsuz nitelikteki sonuçlardan bazıları; iş memnuniyetsizliği, yabancılaşma, örgütsel bağll1ıkta azalma, performans düşüklügüu, moral, motivasyon, örgüte güven ve örgütsel vatandaşlık davranışında azalma, işe devam oranında düşme (Andersson ve Bateman, 1997; Johnson ve O 'Leary Kelly, 2003; Abraham, 2000; Naus, 2007) şeklinde sıralanabilir.

\section{3. İşten Ayrılma Niyeti}

İşten ayrılma niyeti, çalışanda çalışma koşullarından memnun olmama sonucunda oluşan işe bırakmaya yönelik olumsuz ve aktif bir düşünce şeklidir (Rusbelt vd., 1988: 599). Başka bir ifadeyle, işten ayrılma niyeti çalışanın yakın gelecekte örgütten ayrılma isteğiyle ilgili düşüncesini ifade etmektedir (Long vd., 2012: 576). Bu noktada işgören, işyerinden ayrılmaya yönelik kasıtlı ve ihtiyatlı bir niyete sahip olacaktır (Barttlett, 1999: 70; Sabuncuoğlu, 2007: 617). Sözkonusu niyet, bireyin işinden ayrılma davranışı göstermek üzere olduğunun en önemli habercisidir (Tett ve Meyer, 1993: 259; Yıldız vd., 2013: 159).

İşten ayrılma davranışı bireyin kendisine isteklerini daha iyi karşılar düzeyde başka bir iş bulması ile sonuçlanırsa, bu davranışın birey açısından olumlu olduğu söylenebilir. Ancak, işletmeler açısından düşünüldügü̈nde, işten ayrılma davranışının pek çok olumsuz sonuçları bulunmaktadır. Bu konuda yapılan pek çok çalışma bulunmaktadır. Bu noktada, hem ekonomik hem de sosyal boyutlu sonuçlardan söz edilebilir. Kalifiye bir çalışanın işten ayrılmasıyla yerine alınacak birey/bireylere verilecek eğitim masrafları ekonomik boyutu oluştururken çalışanın işini bırakmasıyla geriye kalan diğer örgüt çalışanları arasındaki sosyal ilişkiler ve etkileşimin eksik kalması, çalışanlar arasında gergin ve kaygılı bir bekleyişin başlaması, işe yeni başlayan çalışanın örgüte kolay uyum sağlayamaması ya da kolay kabullenilmemesi ise sosyal boyutlu sonuçlardandır (Kanten, 2014: 14).

İşletmelerin çalışanlarının işten ayrılması sonucu katlanacağı kayıplardan kaçınması için nitelikli çalışanlarını örgütte tutabilmesi ve işten ayrılmaların önüne geçmesi büyük önem taşımaktadır (Bingöl, 1997: 161). Bu nedenle, işten ayrılma niyetinin yukarıda verilen olumsuz sonuçlarından kaçınmak için işletmelerde bazı tedbirlerin alınması faydalı olacaktır. Bunun için, öncelikle işten ayrılma niyetine neden olan faktörler incelenmelidir. Bu faktörler, çevresel, iş ile ilişkili ve kişisel faktörler olarak sıralanabilir (Cotton ve Tuttle, 1986). Kişisel faktörler arasında emeklilik, sağlik durumu, evlenme ve ölüm gibi aile ilişkilerinde meydana gelen değişimler, iş ortamından beklentiler gibi unsurlar bulunmaktadır (Ökten, 2008; Tilki, 2016). Örneğin, Weisberg ve Kirschenbaum (1991), yaş ve deneyim süresi ile işten ayrılma niyeti arasında negatif bir ilişki ve eğitim seviyesi ve mesleki gelişim düzeyi ile işten ayrılma niyeti arasında pozitif yönlü bir ilişki tespit etmiştir. Benzer 
sonuçlara Nogueras (2006) da ulaşmıştır. Ancak, Mor Barak ve diğerleri (2001) demografik değişkenlerle işten ayrılma niyeti arasında anlamlı bir ilişki bulamamıştır. İş ile ilişkili faktörler içinde ise rol belirsizlikleri, olumsuz çalışma koşulları, ücret yetersizliği, iş yükü fazlalığı gibi unsurlar yer almaktadır (Tilki, 2016). Çevresel faktörler içerisinde ise mevsimlere göre meydana gelen dalgalanmalar ve ekonomik olarak yaşanan daralma veya genişleme gibi konjoktürel faktörler, malzeme eksikliği ya da siparişlerin az oluşu gibi piyasa değişmeleri sıralanabilir (Serçeoğlu, Yalçın ve Çetinkaya, 2016: 1101).

\subsection{Değişkenler Arasındaki İlişkiler ve Hipotezler}

Kalay vd. (2014), bir kamu üniversitesinde görev yapan 240 akademik ve idari personel üzerinde yaptıkları araştırma sonuçlarına göre psikolojik yıldırma ile örgütsel sinizm arasında istatistiksel olarak anlamlı ve pozitif yönlü bir ilişki tespit etmiştir. Izquierdo, Esteban, Garcġa-Izquġerdo ve Hernandez (2006), psikolojik yıldırmayla (psikolojik şiddetle) tükenmişlik ve sinizm arasında pozitif ve anlamlı ve psikolojik yıldırmayla psikolojik iyilik arasında negatif yönlü ve anlamlı bir ilişki olduğunu belirlemiştir (Aktaran Aslan ve Akarçay, 2013).

Balducci vd., (2009) ise, psikolojik yıldırma ile sinizm arasında istatistiki olarak herhangi bir anlamlı ilişki bulamamıştır. Aslan ve Akarçay (2013), psikolojik yıldırmayla örgütsel sinizm arasında anlamlı bir ilişki gözlemiş ve örgütsel sinizmin alt boyutları olan bilişsel ve duyuşsal sinizmle psikolojik yıldırma arasında anlamlı bir ilişki tespit etmiş fakat davranışsal sinizmle psikolojik yıldırma arasında herhangi anlamlı bir ilişkiye rastlamamıştır.

Psikolojik yıldırmayla örgütsel sinizmin boyutları arasındaki ilişkiyi akademisyenler üzerinde inceleyen bir başka çalışmada, psikolojik yıldırmayla örgütsel sinizm ve tüm alt boyutları (bilişsel, duyuşsal ve davranışsal) arasında pozitif yönlü bir ilişki bulunmuştur (Bedük vd., 2017). Gül ve Ağıröz (2011), sağlık sektöründe psikolojik yıldırmayla örgütsel sinizme ait duyuşsal sinizm boyutu arasında anlamlı ve olumlu yönde bir ilişki tespit etmiş fakat psikolojik yıldırmayla bilişsel ve davranışsal sinizm arasında anlamlı bir ilişkiye rastlamamıştır. Ayduğan (2012), otel işletmesi çalışanlarında psikolojik yıldırma ile örgütsel sinizm arasında kuvvetli ve pozitif yönlü bir ilişki olduğunu belirlemiştir.

Örgütsel sinizm, işgörenlerin olumsuz işletme koşullarına verdikleri cevap olarak ifade edilebilir (Abraham, 2000; Naus vd., 2007; Kalay vd., 2014). Psikolojik yıldırma işyerinde çalışanın gördüğü psikolojik şiddet ve yıldırma davranışlarını içermektedir. Dolayısıyla işyerinde psikolojik yıldırmaya maruz kalan çalışan işinden memnun olmazsa örgüte bağlllığı azalarak işini sevmez ve işine daha az değer verir hale gelebilir. Bu durum ise; çalışanın örgütüne karşı kötü duygular beslemesine ve örgütsel sinizm yaşamasına neden olabilir. Bu bilgiler doğrultusunda aşağıda yer alan $\mathrm{H}_{1}$ hipotezi kurulmuştur:

$\mathrm{H}_{1}$ : Çalışanların psikolojik yıldırma algısının örgütsel sinizme ilişkin tutumları üzerinde pozitif yönlü ve anlamlı bir etkisi vardır.

İşten ayrılma niyeti, çalışan bireylerin iş koşullarından duydukları negatif yönlü duygulara karşı gösterdikleri olumsuz tepkilerdir (Rusbult, Farrell, Rogers ve Mainous, 1988). Psikolojik yıldırma ile işten ayrılma niyeti arasındaki ilişkiyi inceleyen çalışmalar değişkenler arasında doğrudan ve yüksek dereceli bir ilişki bulmuştur (Cordes ve Dougherty, 1993, Jackson \& Maslach, 1982). Akbolat, Yılmazer ve Tutar (2014), psikolojik yıldırmanın alt boyutları olan özel yaşama yönelik, kişisel gelişimi engellemeye yönelik, görevin yapılmasına yönelik ve iletişim kurmaya yönelik psikolojik yıldırma boyutlarının işten ayrılma niyeti üzerinde istatistiki olarak anlamlı bir etkisinin bulunmadığı fakat kurbanı aşağılamaya yönelik, dışlama ve sözlü ve fiziksel psikolojik yıldırma boyutlarının işten ayrılma niyetini istatistiki olarak anlamlı bir şekilde etkilediğini tespit etmiştir. Çalışma ortamında psikolojik yıldırmaya uğrayan işgörenlerin işe ilişkin verimlikleri, motivasyonları, işe bağlılıkları azalmakta ve bu durum çalışanların işten ayrılma niyetlerinin artmasına neden olmaktadır (Rayner ve Cooper, 1997; Zapf ve Gross, 2001; Tınaz, 2006; Aylan ve Koç, 2016). Bu bilgiler doğrultusunda aşağıda yer alan $\mathrm{H}_{2}$ hipotezi kurulmuştur:

$\mathrm{H}_{2}$ : Çalışanların psikolojik yıldırma algısının işten ayrılma niyetleri üzerinde pozitif yönlü ve anlamlı bir etkisi vardır.

Literatürde psikolojik yıldırma ile işten ayrılma niyeti ilişkisinde örgütsel sinizmin aracılık etkisine yönelik sınırlı sayıda çalışma (Tilki, 2017) bulunmaktadır. 
$\mathrm{H}_{3}$ : Çalışanların psikolojik yıldırma algısı ile işten ayrılma niyeti ilişkisinde örgütsel sinizmin aracılık etkisi vardır.

\section{Araştırmanın Yöntemi}

Metodoloji kısmında çalışmanın amacı, değişkenler arasındaki ilişkiler ve hipotezler, evren ve örneklem, veri toplama yöntemi konularına değinilmiştir.

\section{1. Çalışmanın Amacı ve Önemi}

İşe yönelik olumsuz tutum ve davranışlar, işletme yöneticilerini örgütsel hedefe ulaşmak noktasında zorlayan durumlardır. Özellikle, psikolojik yıldırma ve örgütsel sinizm konuları geçmişten günümüze pek çok işyerinin önemli sorunlarından biri olarak görülmektedir. Einarsen ve Raknes (1997) tarafından Norveç tersanesinde 480 erkek çalışan üzerine yapılan bir araştırmada, hem işçilerin hem de amirlerin yüksek bir kısmının çalışma saatleri boyunca iş arkadaşları ve yöneticileri tarafından aşağılandıkları ve kötü muameleye maruz kaldıkları görülmüştür.

Gerek yerli ve gerekse yabancı literatürde psikolojik yıldırma, örgütsel sinizm ve işten ayrılma niyetine ilişkin çalışmalar genellikle psikolojik yıldırmayı örgütsel sinizmin belirleyicisi olarak ele almış (Aslan ve Akarçay, 2013; Kalay vd. 2014, Pelit ve Pelit, 2014; Erdirençelebi ve Yazgan, 2017) ve işten ayrılma niyetini ise psikolojik yıldırmanın bir sonucu olarak değerlendirmiştir (Jackson ve Maslach, 1982; Cordes ve Dougherty, 1993, Akbolat, Yılmazer ve Tutar, 2014). Ancak, psikolojik sözleşme ile işten ayrılma niyeti arasında örgütsel sinizmin aracılık etkisini inceleyen çalışma (Tilki, 2017) sayısı çok sınırlıdır. Dolayısıyla, literatüre bu anlamda katkı sunulması amaçlanmaktadır.

\subsection{Evren ve Örneklem}

Araştırmanın ana kütlesini Ankara ilinde bulunan 4 yıldızlı otel çalışanları oluşturmaktadır. Ankara Kültür ve Turizm İl Müdürlüğü resmi internet sitesinden edinilen bilgilere göre, Ankara da 42 tane 4 yıldızlı otel bulunmaktadır. Tesadüfi yöntemle otel isim listesinden seçilen 10 otelde araştırma yapılması planlanmıştır. Otellerle yapılan görüşmeler sonrasında 10 otelden 7 tanesi anket teklifini kabul etmiş ve uygulama 2018 Eylül-Ekim döneminde bu 7 otelde gerçekleştirilmiştir. Bu otellerin yetkili personelinden edinilen bilgilere göre, 7 otelde toplam 800 çalışan bulunmaktadır. Dolayısıyla, araştırmanın ana kütlesi 800 çalışandan oluşmaktadır. Anketler otellere bırakılmış ve bir hafta yapılması için süre verilerek süre sonunda teslim alınmıştır. Anketlerin iş ortamında değil çalışanların mesai dışında en rahat oldukları saatler içinde doldurulması gerektiği bilgisi verilmiştir. Sekaran' a (2003:294) göre, elde edilen sonuçların geneli en iyi şekilde temsil etmesi için \%95 güvenilirlik ve $\% 5$ hata payıyla ulaşılması gereken örneklem sayısı 260 ' dır. Uygulanan anketlerden 48 tanesi eksik ve hatalı doldurma nedeni ile analiz dışında bırakılmıştır. Kullanılabilir 267 adet tam olarak doldurulmuş anket analize tabi tutulmuştur.

\subsection{Veri Toplama Yöntemi}

Araştırma verileri anket aracılığıyla toplanmıştır. Çalışmada anket formu dört kısımdan oluşmaktadır. Birinci bölümde, personelin sinizme ilişkin algılarını ölçen "örgütsel sinizm" ölçeği, ikinci kısımda personelin psikolojik yıldırma algısını değerlendiren "psikolojik yıldırma" ölçeği, üçüncü kısımda çalışanların işten ayrılma niyetlerini ölçen "işten ayrılma niyeti" ölçeği ve son kısımda ise personelin demografik özelliklerine ilişkin bilgiler yer almaktadır. Örgütsel sinizm ölçeği olarak Dean ve diğerlerinin (1998) geliştirdiği bilişsel, duyuşsal ve davranışsal boyutlardan oluşan 14 ifade içeren ölçek kullanılmıştır. Ölçeği gerek Türkiye'de (Ayduğan, 2012; Tükeltürk, Perçin ve Güzel, 2009; Kalağan, 2009; Efilti, Gönen ve Öztürk, 2008; Erdost, Karacaoğlu ve Rehanoğlu 2007) gerekse yurtdışında (Brandes, Das ve Hadani, 2006; Brandes ve Das, 2005; Fitzgerald, 2002; Brandes, Dharwadkar ve Dean, 1999) kullanan çok sayıda çalışma mevcuttur.

Anketin ikinci kısmında yer alan psikolojik yıldırma algısı ölçeğinin oluşturulmasında Leymann (1990)'ın psikolojik yıldırma tipolojisinde bulunan 45 farklı davranışı içerisinde barındıran Psikolojik Terör Envanteri (LIPT)'nden yararlanılmıştır. Bu davranışlar, kendini gösterme ve iletişim oluşumuna yönelik saldırılar, sosyal ilişkilere yönelik saldırılar, kişinin itibarına yönelik saldırılar, kişinin yaşam kalitesine ve meslek durumuna yönelik saldırılar ve kişinin sağlığına yönelik saldırılar şeklinde 5 boyuttan oluşmaktadır. Leymann psikolojik yıldırma ölçeği, Davenport vd.'nin (2003) çalışmasının Türkçe formundan yararlanarak oluşturulmuştur. 
Son kısımdaki işten ayrılma niyeti ölçeğinde ise Wayne, Shore ve Liden (1997) ölçeği ile Rusbult ve diğerleri (1988)'nin ölçeğinden yararlanılarak oluşturulan ve Karataş (2013) tarafından kullanılan 6 ifadeden oluşan ölçekten faydalanılmıştır. Araştırmada kullanılan tüm ölçekler 1=Kesinlikle Katılmıyorum......5=Kesinlikle Katılıyorum şeklinde 5'li Likert ölçeği olarak düzenlenmiştir.

\section{Bulgular}

Bu başlık kapsamında araştırmanın örneklemini oluşturan otel çalışanlarında örgütsel sinizm, psikolojik yıldırma algısı ve işten ayrılma niyetleri arasındaki ilişkiyi belirlemek üzere sorulan sorulardan edinilen bulgulara yönelik değerlendirmeler sunulmuştur.

Tablo 1: Demografik Bilgiler

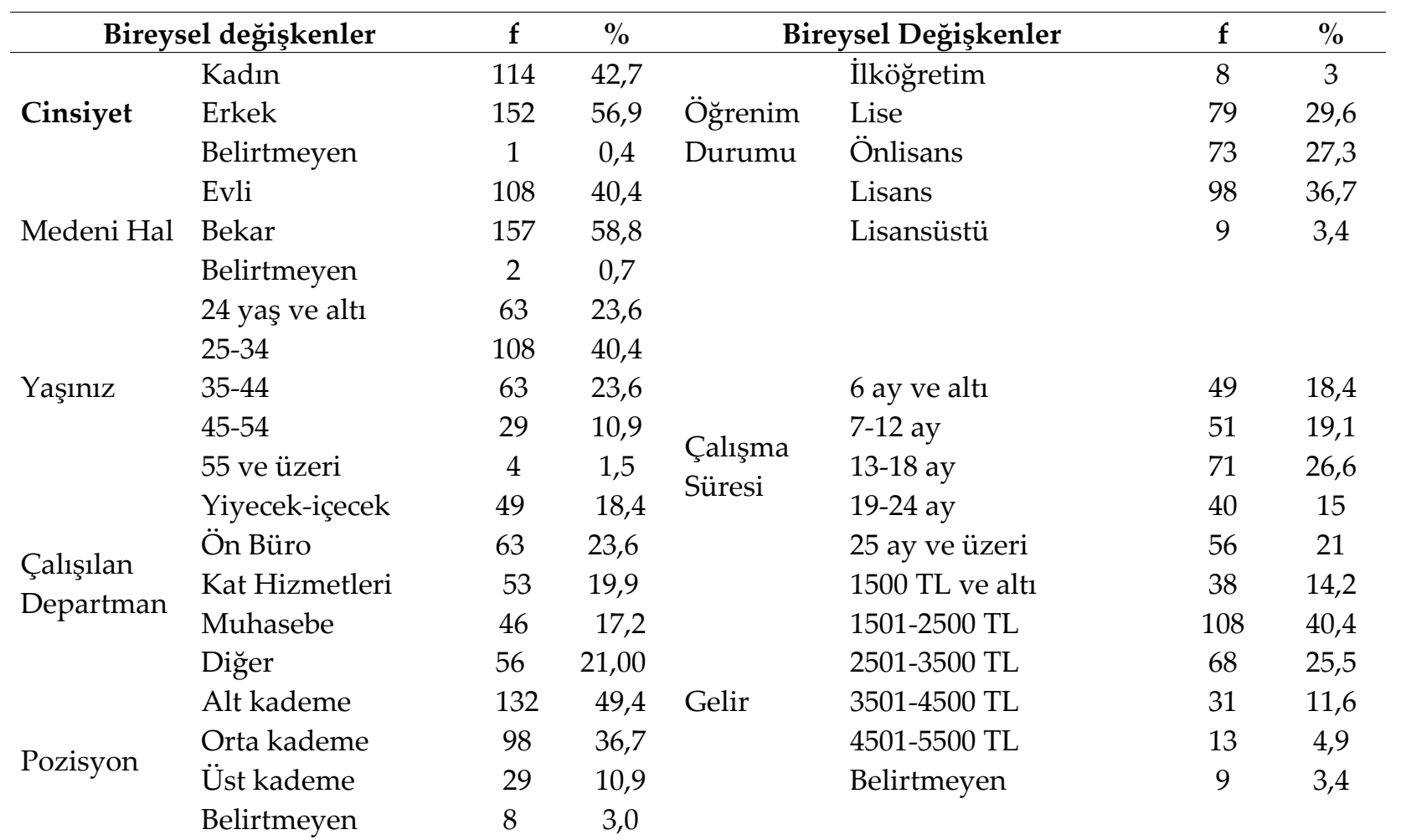

Tablo 1'de yer alan demografik bilgilere göre; araştırmaya katılan çalışanların değişenlere ait en yüksek değerleri verilecek olursa, \%56,9'luk oranla erkek katılımcı çoğunluktadır. \%58,8'i bekardır. 25-34 yaş aralığında katılımcılar daha yoğundur. Çalışanların \%23,6'sı ön büro görevlisidir. Daha çok \%49,4'lük oranla alt kademe çalışanlar bulunmaktadır. Eğitim durumuna göre, \%29,6'sı lise mezunudur. \%26,6'sı, 13-18 ay arasında mevcut işyerinde çalışmaktadır. \%40,4'ü ise, 1501-2500 TL arasında ücret almaktadır.

\subsection{Geçerlilik ve Güvenilirlik}

Ölçeklerin güvenilirliği Cronbach Alfa katsayılarına bakılarak kontrol edilmiştir. Örgütsel sinizm ölçeğinde yer alan 4 sorunun güvenilirlik katsayılarının 0,30'un altında olması ve ölçeğin güvenilirlik değerini düşürmesinden dolayı analiz dışında bırakılmıştır. Bu nedenle, örgütsel sinizm ölçeğinde kalan 10 soruyla analizlere devam edilmiştir. Tablo 2'ye göre, psikolojik yıldırma algısının güvenilirlik katsayısı 0,968; örgütsel sinizmin 0,953 ve işten ayrılma niyetinin ise 0,864'tür. Bu durumda, ölçeklerin güvenirlik katsayıları 0,70'in oldukça üzerinde olduğu için güvenilirliklerinin de oldukça yüksek olduğu (Altunışık vd., 2012) söylenebilir.

Tablo 2: Ölçeklerin Geçerlilik ve Güvenilirlik Katsayıları

\begin{tabular}{llc}
\hline Ölçekler & İfade Sayısı & Cronbach Alfa Katsayısı \\
\hline Psikolojik yıldırma Algısı & 43 & 0,968 \\
Örgütsel Sinizm & 10 & 0,953 \\
İşten Ayrılma Niyeti & 6 & 0,864 \\
\hline
\end{tabular}




\subsection{Faktör Analizi}

Ölçek değişkenlerinin karşılıklı ilişkileri korelasyon analizi yapılarak ve verilerin faktör analizi için uygunluğu ise KMO (Kaiser-Meyer-Olkin) testi yapılarak belirlenmiştir. Buna göre, ölçeklerin KMO değeri 0,947 ve Barlett testi değeri ise 0,000 çıkmıştır. Bu bilgilere göre, veriler açıklayıcı faktör analizi yapabilmek için uygundur. Psikolojik yıldırma algısı, örgütsel sinizm ve işten ayrılma niyeti arasındaki ilişkileri belirlemek için Pearson Korelasyon Analizi uygulanmıştır.

Tablo 3: Korelasyon Analizi Sonuçları

\begin{tabular}{|c|c|c|c|c|c|c|c|c|c|c|}
\hline & ORT & $\begin{array}{l}\text { STD. } \\
\text { SAPMA }\end{array}$ & A & B & C & D & $\mathrm{E}$ & $\mathbf{F}$ & G & $\mathbf{H}$ \\
\hline Örg.Sinizm (A) & 2,26 & 0,93 & 1 & & & & & & & \\
\hline $\begin{array}{l}\text { Psi. Yıldırma } \\
\text { Algısı (B) }\end{array}$ & 1,96 & 0,68 & $0,733^{* *}$ & 1 & & & & & & \\
\hline $\begin{array}{l}\text { Yaş.Mes.Kal. } \\
\text { Yıld. (C) }\end{array}$ & 2,06 & 0,84 & $0,772^{* *}$ & $0,924^{* *}$ & 1 & & & & & \\
\hline $\begin{array}{l}\text { Sos.Hay.İlş. } \\
\text { Yild. (D) }\end{array}$ & 1,87 & 0,78 & $0,411^{* *}$ & $0,748^{* *}$ & $0,497^{* *}$ & 1 & & & & \\
\hline $\begin{array}{l}\text { Gen.Sağ.İlş. } \\
\text { Yild. (E) }\end{array}$ & 1,72 & 0,77 & $0,406^{* *}$ & $0,743^{* *}$ & $0,533^{* *}$ & $0,682^{* *}$ & 1 & & & \\
\hline $\begin{array}{l}\text { İletş.Kurm.İlş. } \\
\text { Ylld. (F) }\end{array}$ & 2,2 & 1,02 & $0,640^{* *}$ & $0,705^{* *}$ & $0,673^{* *}$ & $0,375^{* *}$ & $0,399^{* *}$ & 1 & & \\
\hline İtibar.İlş.Yıld. (G) & 1,87 & 0,77 & $0,396^{* *}$ & $0,730^{* *}$ & $0,493^{* *}$ & $0,737^{* *}$ & $0,609^{* *}$ & $0,409^{* *}$ & 1 & \\
\hline İşt.Ayr.Nyt. (H) & 3,02 & 1,18 & $0,452^{* *}$ & $0,760^{* *}$ & $0,710^{* *}$ & $0,592^{* *}$ & $0,658^{* *}$ & 0,485 & $0,690^{* *}$ & 1 \\
\hline
\end{tabular}

${ }^{* *} \mathrm{p}<0,01$; A: Yaşam ve Meslek Hayatı Kalitesine İlişkin Yıldırma; B: Psikolojik Yıldırma Algısı, C: Örgütsel Sinizm; D: Sosyal Hayata İlişkin Yıldırma; E: Genel Sağlığa İlişkin Yıldırma; F: İletişim Kurma İmkanına İlişkin Yıldırma; G: İşten Ayrılma Niyeti; H: İtibara İlişkin Yıldırma.

Tablo 3' te yer alan bilgiler incelendiğinde; ölçek değişkenleri olan psikolojik yıldırmanın alt boyutları, örgütsel sinizm ve işten ayrılma niyeti değişkenleri arasında istatistiki olarak anlamlı bir ilişki olduğu görülecektir. Psikolojik yıldırma alt boyutları ve örgütsel sinizm ile psikolojik yıldırma alt boyutları ve işten ayrılma niyeti arasında kuvvetli bir ilişki varken örgütsel sinizm ve işten ayrılma niyeti arasında zayıf yönlü ancak anlamlı bir ilişki olduğu söylenebilir.

Tablo 4: Dönüştürülmüş Faktör Matrisi

\begin{tabular}{|c|c|c|c|c|}
\hline $\mathbf{A}$ & $\mathbf{B}$ & $\mathbf{D}$ & $\mathbf{E}$ & G \\
\hline \multicolumn{5}{|l|}{ Çalıştığım kurumla ilgili olarak, } \\
\hline Otelin, söylediği ile yaptığının başka olduğuna inanıyorum. & 0,700 & & & \\
\hline $\begin{array}{l}\text { Otelin, yapacağını belirttiği/söylediği şeyler ile gerçekleşenler ara- } \\
\text { sında benzerlik görmüyorum. }\end{array}$ & 0,755 & & & \\
\hline $\begin{array}{l}\text { Otel, bir şeyi yapmayı planladığını söylüyor ise bunun gerçekleşeceği } \\
\text { konusunda kuşku duyuyorum. }\end{array}$ & 0,697 & & & \\
\hline $\begin{array}{l}\text { Otelin politikaları, amaçları ve uygulamalarında ortak nokta oldu- } \\
\text { ğunu düşünmüyorum. }\end{array}$ & 0,678 & & & \\
\hline Otelde, hak edene hak ettiği ödül (itibar, terfi vb.) imkanı sunulmaz. & 0,609 & & & \\
\hline $\begin{array}{l}\text { Oteli düşündüğüm zaman içimde bir sıkıntı (kaygı, endişe) hissediyo- } \\
\text { rum. }\end{array}$ & 0,688 & & & \\
\hline Oteli düşündüğüm zaman geriliyorum. & 0,673 & & & \\
\hline Otele ait sloganlar/uygulamalarla dalga geçtiğimin farkına vardım. & 0,598 & & & \\
\hline Oteli düşündüğüm zaman sinirleniyorum. & 0,627 & & & \\
\hline Otel beni kızdırıyor. & 0,613 & & & \\
\hline Üstüm kendimi gösterme olanaklarımı kısıtlıyor. & & & 0,789 & \\
\hline Sözüm kesiliyor. & & & 0,803 & \\
\hline $\begin{array}{l}\text { Meslektaşlarım ve iş arkadaşlarım kendimi gösterme olanaklarımı k1- } \\
\text { sıtlıyor. }\end{array}$ & & & 0,713 & \\
\hline
\end{tabular}


Yüzüme bağırılıyor ve yüksek sesle azarlanıyorum.

0,611

Yaptığım iş eleştiriliyor.

Özel yaşamım eleştiriliyor.

0,572

Telefon ile rahatsız ediliyorum.

0,610

Sözlü tehditler alıyorum.

Yazılı tehditler alıyorum.

0,658

Jestler/bakışlar yolu ile ilişkilerim reddediliyor.

0,422

0,651

0,708

İmalar yolu ile ilişkilerim reddediliyor.

Çevremdeki insanlar benimle konuşmaktan kaçınıyor.

0,681

Konuşmak için başkalarına ulaşmam engelleniyor.

0,739

Bana diğer arkadaşlarımdan ayrılmış bir işyeri-ofis veriliyor. $\quad 0,689$

\begin{tabular}{ll}
\hline Meslektaşlarımın benimle sohbet etmesi yasaklanıyor. & 0,775
\end{tabular}

\begin{tabular}{lc}
\hline Sanki orada yokmuşum gibi davranılıyor. & 0,786
\end{tabular}

\begin{tabular}{lc}
\hline İnsanlar arkamdan kötü konuşuyorlar. & 0,771
\end{tabular}

\begin{tabular}{lc}
\hline Hakkımda asılsız söylentiler ortaya atılıyor. & 0,771
\end{tabular}

Gülünç durumlara düşürülüyorum. $\quad 0,762$

\begin{tabular}{ll}
\hline Psikolojik değerlendirmeden geçmem için bana baskı yapılır. & 0,766
\end{tabular}

Bir özürüm ile alay edilir.

Dini ya da siyasi görüşümle dalga geçiliyor.

0,756

0,753

Özel yaşamım alay konusu oluyor.

0,768

Milliyetimle/etnik kökenimle alay ediliyor.

0,733

Özgüvenimi olumsuz etkileyen bir iş yapmaya

zorlaniyorum.

Çabalarım yanlış ve küçültücü bir şekilde yargılanıyor.

Kararlarım sorgulanıyor.

Alçaltıcı isimlerle anılırım.

Cinsel imalarda bulunuluyor.

Bana göre özel görev yoktur.

Bana verilen işler geri alınıyor ve kendime yeni bir iş bile bulamıyorum.

(2)

\begin{tabular}{ll}
\hline Yerine getirmem için bana anlamsız bir takım işler veriliyor. & 0,685 \\
\hline Sahip olduğumdan daha az yetenek gerektiren işler bana veriliyor. & 0,715 \\
\hline İşim (görevim) sürekli değiştiriliyor. & 0,812 \\
\hline Özgüvenimi etkileyecek işler veriliyor. & 0,737 \\
\hline $\begin{array}{l}\text { İtibarımı olumsuz etkileyecek şekilde, niteliklerimin dişındaki işler ve- } \\
\text { riliyor. }\end{array}$ & 0,650 \\
\hline Bana mali yük getirecek zararlara sebep olunuyor. & 0,597 \\
\hline Evime/işyerime zarar veriliyor. & 0,729 \\
\hline Fiziksel olarak ağır işler yapmaya zorlanıyorum. & 0,790 \\
\hline Fiziksel şiddet tehditleri alıyorum. & 0,778 \\
\hline Gözümü korkutmak için hafif şiddet uygulanıyor. & 0,670 \\
\hline Fiziksel zarar verilir. & 0,742 \\
\hline Doğrudan cinsel tacize uğrarım. & 0,721 \\
\hline Daha iyi bir iş bulur bulmaz ayrılacağım. & 0,987 \\
\hline Her an istifa kararı verebilirim. & 0,965 \\
\hline Şu anda aktif bir şekilde dişarıda iş arıyorum. & 0,897 \\
\hline Alternatif iş tekliflerini kabul edebilirim. & 0,990 \\
\hline Ciddi bir biçimde işten ayrılmayı düşünüyorum. & 0,865 \\
\hline Siklıkla işimden ayrılmayı düşünüyorum. & 0,945 \\
\hline
\end{tabular}

A: Yaşam ve Meslek Hayatı Kalitesine İlişkin Yıldırma; B: Örgütsel Sinizm; C: Sosyal Hayata İlişkin Yıldırma; D: Genel Sağlığa İlişkin Yıldırma; E: İletişim Kurma İmkanına İlişkin Yıldırma; F: İşten Ayrılma Niyeti; G: İtibara İlişkin Yıldırma. 
Veri setine ilişkin gerçekleştirilen faktör analizi sonuçlarına göre (Bkz. Tablo 4); örgütsel sinizm soruları tek boyutta, psikolojik yıldırma algısı soruları 5 boyutta ve işten ayrılma niyeti ölçeği soruları tek boyutta toplanmıştır. Psikolojik yıldırma algısı ölçeği orijinalinde olduğu gibi 5 boyuta ve işten ayrılma ölçeği orijinalinde olduğu gibi tek boyuta ayrılmış fakat örgütsel sinizm ölçeği güvenilirlik analizi sırasında analiz dışı bırakılan 4 sorudan dolayı orijinalinde olduğu gibi 3 boyuta değil tek boyuta ayrılmıştır. Bu durum, araştırmanın uygulandığı örneklem için geçerli olan bir ölçek yapısını ortaya koymuştur. Psikolojik yıldırma algısı alt boyutları ise; iletişim kurma imkanına ilişkin yıldırma, sosyal hayata ilişkin yıldırma, itibara ilişkin yıldırma, yaşam ve meslek hayatı kalitesine ilişkin yıldırma, genel sağlığa ilişkin yıldırma şeklinde adlandırılmıştır.

\subsection{Hiyerarşik Regresyon Analizi}

Psikolojik yıldırma algısı ile işten ayrılma niyeti ilişkisinde örgütsel sinizmin aracılık etkisini incelemek amacıyla hiyerarşik regresyon analizi yapılmıştır. Değişkenler arasındaki çoklu bağlantı sorunu giderildikten sonra ortaya çıkan merkezileştirilmiş değerler (Cohen vd., 2003’ den Akt. Frazier, Tix ve Barron, 2004: 120) analize dahil edilmiştir.

Tablo 5: Hiyerarşik Regresyon Analizi Bulguları

\begin{tabular}{|c|c|c|c|}
\hline \multirow[t]{2}{*}{ Değişken Adı } & Örgütsel Sinizm & İşten Ayrulma Niyeti & $\begin{array}{l}\text { İşten Ayrulma Ni- } \\
\text { yeti }\end{array}$ \\
\hline & $\beta$ & $\beta$ & $\beta$ \\
\hline \multicolumn{4}{|l|}{ Model 1} \\
\hline Psikolojik Yıldırma Algısı & $0,733^{*}$ & & \\
\hline $\mathrm{F}$ & 307,278 & & \\
\hline $\mathrm{R}^{2}$ & 0,54 & & \\
\hline Düzeltilmiş R² & 0,537 & & \\
\hline \multicolumn{4}{|l|}{ Model 2} \\
\hline Psikolojik Yıldırma Algısı & & $0,540^{*}$ & \\
\hline $\mathrm{F}$ & & 298,210 & \\
\hline $\mathrm{R}^{2}$ & & 0,473 & \\
\hline Düzeltilmiş $\mathrm{R}^{2}$ & & 0,470 & \\
\hline \multicolumn{4}{|l|}{ Model 3} \\
\hline Psikolojik Yıldırma Algısı & & & 0,320 \\
\hline Örgütsel Sinizm & & & $0,535^{*}$ \\
\hline $\mathrm{F}$ & & & 86,582 \\
\hline $\mathrm{R}^{2}$ & & & 0,310 \\
\hline $\begin{array}{l}\text { Düzeltilmiş } R^{2} \\
* p<0,05\end{array}$ & & & 0,305 \\
\hline
\end{tabular}

Tablo 5'te yer alan hiyerarşik regresyon analizi bulgularına göre, Model 1'de psikolojik yıldırma bağımsız değişken iken örgütsel sinizm bağımlı değişkendir. Model 2'de psikolojik yıldırma bağımsız değişken iken işten ayrılma niyeti bağımlı değişkendir. Modeli 3'te ise, psikolojik yıldırma algısı ve örgütsel sinizm bağımsız değişken iken işten ayrılma niyeti bağımlı değişken olarak analiz edilmiştir. Analiz sonuçlarına göre, Model 2'de 0,540 olan psikolojik yıldırma algısı $\beta$ değeri Model 3'te 0,320'ye düşmüştür ve istatistiki olarak anlamlı değildir. Aracılık etkisi araştırılırken, bağımlı değişkenle bağımsız değişken arasındaki ilişki düzeyinin düşmesi ve anlamlılığını kaybetmesi, aracı değişkenin anlamlılık düzeyini koruması ve aracı değişkenle birlikte bağımlı değişkenin anlamlılığını koruması durumu aracılık etkisinin varlığını göstermektedir (Baron ve Kenny, 1986: 1173). Bu açıdan incelendiğinde, örgütsel sinizmin psikolojik yıldırma algısı ve işten ayrılma niyeti arasında tam aracılık etkisi olduğunu göstermektedir. Bu sonuca göre (Tablo 5); $\mathrm{H}_{1}, \mathrm{H}_{2}$ ve $\mathrm{H}_{3}$ hipotezleri kabul edilmiştir.

\section{Sonuç ve Tartışma}

Çağımızın en önemli üretim faktörü olarak kabul edilen "insan-emek" unsurundan en yüksek düzeyde verimin alınabilmesi için öncelikle insanı anlamak ve doğru yorumlamak gerekmektedir. Çalışanların işlerine yönelik tutumları onların işlerine ve örgütlerine olan bağlılıklarını ve aidiyet duygularını etkileyen bir unsurdur. İşe yönelik tutumların olumlu olmasını sağlamak ise örgüt yöneticilerinin elindedir. İşinden ve iş ortamından memnun olmayan, yöneticileri ya da çalışma arkadaşları tarafından rahatsız edilen, psikolojik yıldırmaya uğrayan çalışanlar işe karşı olumsuz tutumlar beslerler. 
İşgörenlerin işe karşı olumsuz tutum ve davranışlarına odaklanan bu çalışmada, otel çalışanları üzerinde psikolojik yıldırma ile işten ayrılma niyeti arasındaki ilişkide örgütsel sinizmin aracılık etkisi araştııılmıştır. Analiz bulgularına göre, örgütsel sinizmin psikolojik yıldırma ile işten ayrılma niyeti arasındaki ilişkide aracılık etkisi anlamlı çıkmıştır. Araştırmada $\mathrm{H}_{1}$ hipotezi "çalışanların psikolojik yıldırma algısının örgütsel sinizme ilişkin tutumları üzerinde pozitif yönlü ve anlamlı bir etkisi vardır" ifadesi analizler doğrultusunda desteklenmiştir. Bu yönüyle, araştırma, psikolojik yıldırmayla sinizm etkileşimini inceleyen araştırmalarla (Gül ve Ağıröz, 2011; Khan, 2014; Tilki, 2017) benzerlik göstermektedir. $\mathrm{H}_{2}$ hipotezi olan "çalışanların psikolojik yıldırma algısının işten ayrılma niyetleri üzerinde pozitif yönlü ve anlamlı bir etkisi vardır" ifadesi de analizler sonucunda desteklenmiştir. Araştırma, bu yönüyle daha önce psikolojik yıldırma ve örgütsel sinizm ilişkisini inceleyen araştırmalarla (Leymann, 1996; Rayner ve Cooper, 1997; Zapf ve Gross, 2001; Djurkovic, McCormack ve Casimir, 2004; Yapıc1, 2008; Engin, Oğuzhan ve Ünsar, 2015) benzer sonuçlar ortaya koymuştur. H3 hipotezi "çalışanların psikolojik yıldırma algısı ile işten ayrılma niyeti ilişkisinde örgütsel sinizmin aracılık etkisi vardır" ifadesi de analiz sonuçlarına göre kabul edilmiştir. Daha önce de belirtildiği gibi literatürde bu aracılık ilişkisini inceleyen çalışma sayısı oldukça sınırlıdır. Araştırma, son hipotez açısından Tilki (2017)'nin araştırmasıyla benzer sonuçlar ortaya koymuştur.

Çalışma hayatında psikolojik yıldırma ve örgütsel sinizm gerek çalışan ve gerekse örgüt üzerinde çok büyük zararlara yol açabilir. Öyle ki, literatürde sinizm tükenmişliğin bir alt boyutu olarak değerlendirilmektedir (Esther, 2003). Bu durumda, tükenmişlik yaşayan bir çalışandan örgüte katkı sunmasını beklemek yanlış olacaktır. Özellikle, konaklama işletmelerinde psikolojik yıldırma, yönetim tarafından görmezden gelinen çalışanın yaşadığı baskı, zorlama, fiziksel şiddet ve tacizler vasıtasıyla bireyi işi ve işyerinden uzaklaştırmak için bilinçli ve art niyetli bir olaylar zinciridir (Kaya, 2009: 42). Dolayısıyla, tüm işletmelerde olduğu gibi turizm işletmelerinde de psikolojik yıldırma önemli bir sorun haline gelmiştir. Çalışma ortamında yaşanan psikolojik yıldırma olayları tamamen sosyal bir olgudur. Çünkü, psikolojik yıldırma sadece iki taraf arasında yaşanmaz. Bu süreçte, psikolojik yıldırma; tacizi uygulayan tarafa bilerek ya da bilmeden ortak olma (Çobanoğlu, 2005), gördügü halde sessiz kalma, korkarak ortama uyum sağlama, hiçbir şey olmuyormuş gibi davranma olaylarının geliştiği aslında herkesin sürece dahil olduğu çok taraflı olarak sosyal çevrede yaşananlardır. Özelikle, turizm sektörü gibi çalışanların müşteriyle birebir iletişimine dayanan hizmet işletmelerinde çalışanın işinde kendisini iyi ruh halinde hissetmesi davranışlarına olumlu yansıyarak müşterileriyle daha etkili iletişim kurmasına sebep olacaktır. Bu durumda, müşteriler işletmenin hizmetinden memnun kalmış bir şekilde ayrılacaktır. Dolayısıyla, başarılı olmak isteyen işletmelerin öncelikli olarak çalışanını desteklemesi, sorunlarını dinleyerek çözüm sunması, onları işyerinde rahatsız eden durumları önlemesi gerekmektedir. Öyle ki, Göktaş Kulualp (2018), sağlık çalışanları üzerine yaptığı bir araştırmada, çalışan performansının çalışan motivasyonu ve ödüllendirmeden olumlu yönde etkilendiğini saptamıştır. Dolayısıyla, işletme içerisinde olumsuz iş tutumlarının en aza indirgenmesi ve olumlu iş tutumlarının artırılması ile işletmenin hedeflediği noktaya ulaşması kolaylaşabilir.

Sonuç itibariyle, psikolojik yıldırma ve örgütsel sinizm, işletme ve çalışanlar üzerinde etkili oldukları için yönetilmesi gereken davranışlardır (Kalay vd., 2014: 137). Bu nedenle, psikolojik yıldırma ve örgütsel sinizmin kontrol altına alınması gereken bir süreç yönetimi olduğu söylenebilir. Aksi takdirde, birbirini tetikleyen bir süreç olduğu için işten ayrılma düşüncesine kadar giden olumsuzluklarla karşılaşılabileceği yapılan analizlerle ortaya konmuştur. Bu çalışmanın, işletme yönetimlerini zararla sonuçlanabilecek bir sürece karşı uyarmak suretiyle çalışma hayatına bir katkı sunması beklenmektedir. Çünkü, araştırmada psikolojik yıldırmadan örgütsel sinizme ve örgütsel sinizmden işten ayrılma niyetine giden model analizlerle desteklenmiştir. Ayrıca, bu değişkenlerin ikili gruplar halinde ya da farklı değişkenlerle ilişkilerini inceleyen çok sayıda çalışma olmasına rağmen (Jackson ve Maslach, 1982; Rusbult, Farrell, Rogers ve Mainous, 1988; Rayner ve Cooper, 1997; Cordes ve Dougherty, 1993; Zapf ve Gross, 2001; Tinaz, 2006; Akbolat, Yllmazer ve Tutar, Balducci vd., 2009; 2014; Aylan ve Koç, 2016; Bedük vd., 2017), literatürde bu üç değişkeni tek bir model çatısında araştırarak modelde geçen aracılık etkisini inceleyen sınırlı sayıda çalışmaya rastlanmıştır (Tilki, 2017). Bu anlamda da, çalışmanın literatüre katkı sağlayacağı öngörülmektedir. Bu modelle konunun bir adım daha ileri taşınacağı düşünülerek, ileride yapılacak olan çalışmalar için neden-sonuç odaklı ve çok değiş̧kenli farklı modeller üzerinde çalışılması önerilebilir. 


\section{Kaynaklar}

Abraham, R. (2000). Organizational Cynicism: Bases and Consequences Generic, Social, and General. Psychology Monographs, 126 (3), 269-292.

Adams, A., Bray, F. (1992). Holding Out Against Workplace Harassment And Bullying. Personnel Management, 24 (10), 48-52.

Akbolat, M., Yılmazer, A., ve Tutar, H. (2014). Konaklama İşletmeleri Çalışanlarının Algıladıkları Mobbingin İş Tatmini ve İşte Ayrılma Niyetine Etkisi. Manas Sosyal Araştırmalar Dergisi, 3(3), 1-17.

Akça, R. (2014). Otel İşletmelerinde Mobbing, İş Stresi ve İşgörenlerin İşten Ayrılma Niyetleri Üzerinde Bir Araştırma. Gazi Üniversitesi Eğitim Bilimleri Enstitüsü Yayınlanmamış Yüksek Lisans Tezi, Ankara.

Altunışık, R. Coşkun, R., Bayraktaroğlu, S. ve Yıldırım, E. (2005). Sosyal Bilimlerde Araştırma Yöntemleri: SPSS Uygulamalı. 4. Baskı. İstanbul: Avc1 Ofset.

Andersson, L. M ve Bateman T. S. (1997). Cynicism in The Workplace: Some Causes and Effects. Journal of Organizational Behavior, 18(5), 449-469.

Aslan, Ş., Akarçay, D. (2013). Psikolojik Şiddetin Genel ve Örgütsel Sinizme Etkileri. Erciyes Üniversitesi İktisadi ve İdari Bilimler Fakültesi Dergisi, 41, 25-44.

Ayduğan, N. (2012). Mobbingin Örgütsel Sinizme Etkisi: Beş Yıldızlı Otel İşletmelerinde Bir Uygulama. Afyon Kocatepe Üniversitesi, Sosyal Bilimler Enstitüsü, Basılmamış Yüksek Lisans Tezi, Afyonkarahisar.

Aylan, S. ve Koç, H. (2016). Relationship Between Mobbing and Intention to Leave in Hotel Industry. Journal of Tourism and Gastronomy Studies, 14, 20.

Balducci, C., Alfano, V. ve Fraccaroli, F. (2009). Relationships Between Mobbing at Work and Mmpi-2 Personality Profile, Posttraumatic Stress Symptoms and Suicidal Ideation and Behavior. Violence and Victims, 24(1), 52-67.

Baron, R. M ve Kenny, D. A. (1986). The Moderator-Mediator Variable Distinction in Social Psychological Research: Conceptual, Strategic, and Statistical Considerations. Journal of Personality and Social Psychology, 51(6), 1173-1182.

Bartlett, K. R. (1999). The Relationship Between Training and Organizational Commitment in The Health Care Field. The University of Illınois, Unpubliced Doctoral Thesis, Urbana.

Bassman, E. S. (1992). Abuse in The Workplace: Management Remedies and Bottom Line Impact. Westport CT: Quorum Books.

Bedeian, A. G. (2007). Even if the Tower is 'Ivory', it isn't White: Understanding The Consequences of Faculty Cynicism. Academy of Management Learning \& Education, 6(1), 9-32.

Bedük, A., Eryeşil, K., Altınışık, G. D. (2017). The Relationship Between Mobbing and Organizational Cynicism: an Empirical Study. Journal of Human Sciences, 14(4), 3167-3176.

Bingöl, D. (1997). Personel Yönetimi, İstanbul: Beta Basım Yayım Dağıtım.

Brandes, P., Das, D. ve Hadani, M. (2006). Organizational Cynicism a Field Examination Using Global and Local Social Excahange Relationships and Workplace Outcomes. Charlotte: Information Age Publishing.

Brandes, P., ve Das, D. (2006). Locating Behavioral Cynicism at Work: Construct Issues and Performance Implications. Employee Health, Coping and Metodologies Research in Occupational Stres and Well Being, 5, 233266.

Brandes, P., Dharwadkar, R. ve Dean, J. W. (1999). Does Organizational Cynicism Matter? Employee and Supervisor Perspectives on Work Outcomes. Eastern Academy of Management Proceedings, (Outstanding Empirical Paper Award), 150-153.

Cohen J., Cohen P., West, S. G, Aiken, L. S. (2003). Applied Multiple Regression/Correlation Analysis for the Behavioral Sciences. 3. Baskı, Mahwaj, NJ: Erlbaum. 
Cordes, C. L, ve Dougherty, T. W. (1993). A Review and an Integration of Research in Job Burnout. Academy of Management Review, 18, 621-656.

Cotton, J. L. ve Tuttle, J. M. (1986). Employee Turnover: A Meta-Analysis And Review With Implications For Research. The Academy of Management Review, 11(1), 55-70.

Çalak, A. (2017). Turizm İşletmelerinde Psikolojik Yıldırma (Mobbing). Trakya Üniversitesi Sosyal Bilimler Enstitüsü, Yayınlanmamış Yüksek Lisans Tezi, Edirne.

Çelik, N. (2009). Konaklama İşletmelerinde Çalışanlara Yönelik Yıldırma Davranışları (Mobbing) ve İş Stresi. Mersin Üniversitesi Sosyal Bilimler Enstitüsü, Yayınlanmamış Yüksek Lisans Tezi, Mersin.

Çobanoğlu Ş. (2005). Mobbing-İsyerinde Duygusal Saldırı ve Mücadele Yöntemleri. İstanbul: Timaş Yayınları.

Davenport, N., Schwartz, R. D., ve Elliott, G. P. (2003). Mobbing: İşyerinde Duygusal Yıldırma. (Çev. O. C. Önertoy). İstanbul: Sistem Yayıncilık.

Dean, J., J. W., Brandes, P., ve Dharwadkar, R. (1998). Organizational Cynicism. The Academy of Management Review, 23(2), 341-352.

Djurkovic, N., McCormack, D., Casimir, G. (2004). The Physical and Psychological Effects of Workplace Bullying and Their Relationship to Intention to Leave: A Test of the Psychosomatic and Disability Hypotheses, International Journal of Organization Theory and Behavior, 7(4), 469-497.

Efilti, S., Gönen, Y. Ö. ve Öztürk, Ü.F. (2008). Örgütsel Sinizm: Akdeniz Üniversitesi'nde Görev Yapan Yönetici Sekreterler Üzerinde Bir Alan Araştırması. 7. Ulusal Büro Yönetimi ve Sekreterlik Kongresi, Karadeniz Teknik Üniversitesi, Trabzon, 279- 290.

Einarsen, S. (2000). Harassment and Bullying at Work: A Review of the Scandinavian Approach. Aggression and Violent Behavior, 5(4), 379-401.

Einarsen, S. ve Raknes, B. I. (1997). Harassment in the Workplace and the Victimization of Men. Violence and Victims, 12, 247-263.

Engin, G., Oğuzhan, A. ve Ünsar, S. (2015). Duygusal Tacizin İşten Ayrılma ve Örgütsel Bağlllı̆̆a Olan Etkisi: Konu ile İlgili Bir Araştırma. Verimlilik Dergisi, 4.

Erdirençelebi, M., ve Yazgan, A. E. (2017). Mobbing, Örgütsel Sinizm, Örgütsel Bağlllık ve Bunların Algılanan Çalışan Performansı Üzerine Etkileri. Süleyman Demirel University Journal of Faculty of Economics \& Administrative Sciences, 22, 2.

Erdost, H. E., Karacaoğlu, K. ve Reyhanoğlu, M. (2007). Örgütsel Sinizm Kavramı ve İlgili Ölçeklerin Türkiye'deki Bir Firmada Test Edilmesi. XV. Ulusal Yönetim ve Organizasyon Kongresi, Sakarya, 514-524.

Göktaş Kulualp, H. (2018). Sağlık Sektöründe Çalışan Performansının Değerlendirilmesine Yönelik Bir Yol Analizi. Işletme Araştırmaları Dergisi, 10(4), 600-624.

Greenglass, E. R, Burke, R. J. ve Moore, K. A. (2003). Reactions to Increased Workload: Effects on Professional Efficacy of Nurses. Applied Psychology: An International Review, 52(4), 581.

Fitzgerald, M. R. (2002). Organizational Cynicism: Its Relationship Perceived Organizational Injustice Explanatory Style. A Dissertation Presented to The Division of Research and Advanced Studies of University of Cincinnati.

Frazier, P. A, Tix A. P. ve Barron, K. E. (2004). Testing Moderator and Mediator Effects in Counseling Psychology Research. Journal of Counselling Psychology, 51(1), 115-134.

Gül, H., ve Ağıröz, A. (2011). Mobbing ve Örgütsel Sinizm Arasındaki İlişkiler: Hemşireler Üzerinde Bir Uygulama. Afyon Kocatepe Üniversitesi İktisadi ve İdari Bilimler Fakültesi Dergisi, 13(2), 27-47.

Izquierdo, M. G, Esteban B. Llor, Garcga-Izquġerdo A. L., Hernandez J. A. R. (2006). Psychological Well-Being and Mobbing in a Sample of Employees Working in The Medical and Education Sectors. Bienestar Psicológico y Mobbing en una Muestra de Profesionales de los Sectores Educativo y Sanitario, 22(3), 381-395. 
Jackson, S. E, ve Maslach, C. (1982). After-Effects of Job-Related Stress: Families as Victims. Journal of Occupational Behaviour, 3, 63-77.

Johnson, J. L . ve O'Leary-Kelly, A. M. (2003). The Effects of Psychological Contract Breach and Organizational Cynicism: Not All Social Exchange Violations Are Created Equal. Journal of Organizational Behavior, 24(5), 627-647.

Kalağan, G. (2009). Araştırma Görevlilerinin Örgütsel Destek Algıları ile Örgütsel Sinizm Tutumları Arasındaki İlişki. Akdeniz Üniversitesi Sosyal Bilimler Enstitüsü, Yayımlanmamış Yüksek Lisans Tezi, Antalya.

Kalay, F., Oğrak, A., Nişancı, Z. N. (2014). Mobbing, Örgütsel Sessizlik ve Örgütsel Sinizm İlişkisi: Örnek Bir Uygulama. Kastamonu Üniversitesi İktisadi ve İdari Bilimler Fakültesi Dergisi, 4(2), 127-143.

Karataş A. (2013). Otel İşletmelerinde Kronizmin İş Tatmini ve İşten Ayrılma Niyeti Üzerindeki Etkileri: Muğla İlinde Bir Araştırma. Balıkesir Üniversitesi Sosyal Bilimler Enstitüsü, Yayımlanmamış Yüksek Lisans Tezi, Balıkesir.

Kaya, U. (2009). İşletmelerde Yıldırma Davranışları (Mobbing): İzmir'deki Beş Yıldızlı Şehir Otellerinde Bir Araştırma. Muğla Üniversitesi Sosyal Bilimler Enstitüsü, Yayınlanmamış Yüksek Lisans Tezi, Muğla.

Kaymakcı, H. A. (2008). Çalışma Hayatında Mobbing (Sakarya imalat sektöründe bir araştırma). Sakarya Üniversitesi Sosyal Bilimler Enstitüsü, Yayınlanmamış Doktora Tezi, Sakarya.

Khan, M. A. (2014). Organizational Cynicim and Employee Turnover Intention: Evidence From Banking Sector in Pakistan. Pakistan Journal of Commerce and Social Sciences, 8(1), 30-41.

Kile, S. M. (1990). Helsefarlige ledere og medarbeidere [Health-endangering leaders and coworkers]. Oslo, Norway: Hjemmets Bokforlag.

Leymann, H. (1990). Mobbing and Psychological Terror at Workplaces. Violence and Victims, 5(2), 119-126.

Leymann, H. (1996). The Content and Development of Mobbing at Work. European Journal of Work and Organizational Psychological, 5(2), 165-184.

Mor B. M. E, Nissly J. A. ve Levin, A. (2001). Antecedents to Retention and Turnover Among Child Welfare, Social Work, and Other Human Service Employees: What Can We Learn from Past Research? A Review and Metanalysis. Social Service Review, 625-661.

Morrison, E. W. ve Robinson, S. L. (1997). When Employees Feel Betrayed: a Model of How Psychological Contract Violation Develops. Academy of Management Review, 22(1), 226-256.

Naus, A. J. A. M. (2007). Organizational Cynicism: on The Nature, Antecedents, and Consequences of Employee Cynicism Toward The Employing Organization. Maastricht University, Doctoral Dissertation, Maastricht.

Naus, F., Van I., A. ve Roe, R. (2007). Organizational Cynicism: Extending The Exit, Voice, Loyalty and Neglect Model of Employees' Response to Adverse Conditions in the Workplace. Human Relations, 60, 683-718.

Nogueras, D. J. (2006). Occupational Commitment, Education, and Experience as a Predictor of Intent to Leave the Nursing Profession. Nursing Economics, 24(2), 86-93.

Olweus, D. (1994). Annotation: Bullying at School: Basic Facts and Effects of a School Based Intervention Program. Journal of Child Psychology and Psychiatry, 35, 1171-1190.

Palaz, S., Özkan, S., Sarı, N., Göze, F., Şahin, N. ve Akkurt, Ö. (2008). İş Yerinde Psikolojik Taciz (Mobbing) Davranışları Üzerine Bir Araştırma: Bandırma Örneği. ISGUC The Journal of Industrial Relations and Human Resources, 10(4), 41-58.

Pelit, E. ve Kılıç, İ. (2012). Mobbing ile Örgütsel Bağlllık İlişkisi: Şehir ve Sayfiye Otellerinde Bir Uygulama. İsletme Araştırmaları Dergisi, 4(2), 122-140.

Pelit, E., ve Pelit, N. (2014). The Effects of Mobbing on Organizational Cynicism: A Study on Hotels in Turkey. International Journal of Human Resource Studies, 4(1), 34-56. 
Rayner, C. ve Cooper, C. (1997). Workplace Bullying: Myth or Reality-Can We Afford To Ignore it?. Leadership and Organization Development Journal, 18(4), 211-214.

Rehman, F. U., Javed, F., Khan, A., Nawaz, T., ve Hyder, S. (2015). Determining the Effects of Mobbing on Organizational Commitment: A Case of Educational Sector in Pakistan. Journal of Education and Practice, 6(22), 101-105.

Rusbult, C. E, Farrell, D., Rogers, G., ve Mainous, A. G. (1988). Impact of Exchange Variables on Exit, Voice, Loyalty and Neglect: an Integrative Model of Responses to Declining Job Satisfaction. Academy of Management Journal, 31(3), 599-627.

Sabuncuoğlu, E. T. (2007). Eğitim, Örgütsel Bağlılık ve İşten Ayrılma Niyeti Arasındaki İlişkilerin İncelenmesi. Ege Akademik Bakış, 7(2), 613-628.

Sekaran, U. (2003). Research Methods For Business: A Skill Building Approach. 4th edition, John Willey \& Sons.

Serçeoğlu, N., Işık, Z. ve Çetinkaya, M. Y. (2016). İşyeri Zorbalığının İşten Ayrılma Niyeti Üzerine Etkisi: Konaklama İşletmelerinde Çalışan Personel Üzerine Bir Araştırma. Uluslararası Sosyal Araştırmalar Dergisi, 45(9), 1099-1109.

Shallcross, L. (2003). The Workplace Mobbing Syndrome, Response and Prevention in The Public Sector. Workplace Mobbing Conference, Brisbane.

TETT, R. P., Meyer, J. P. (1993). Job Satisfaction, Organizational Commitment, Turnover Intention and Turnover: Path Analyses Based On Meta- Analytic Findings. Personnel Psychology, 46, $259-293$.

Tınaz, P. (2006). İsyerinde Psikolojik Taciz (Mobbing). İstanbul: Beta Basım Yayım Dağıtım.

Tilki, T. Z. Ö. (2017). Yıldırma, Örgütsel Sinizm, İş Doyumu ve İşten Ayrılma Niyeti İlişkilerinde Seri Aracılık Etkileri: Örgütlerde Engelli Çalışanlar Üzerine Bir Araştırma. Hacettepe Üniversitesi Sosyal Bilimler Enstitüsü, Yayınlanmamış Yüksek Lisans Tezi, Ankara.

Tokgöz, N. ve Yılmaz, H. (2008). Örgütsel Sinisizm: Eskişehir ve Alanya'daki Otel İşletmelerinde Bir Uygulama. Anadolu Üniversitesi Sosyal Bilimler Dergisi, 8(2), 283-305.

Tutar, H. (2004). İşyerinde Psikolojik Şiddet Sarmalı: Nedenleri ve Sonuçları. Yönetim Bilimleri Dergisi, 2(2), 101-128.

Tükeltürk, Ş. A., Perçin, N. Ş., ve Güzel, B. (2009). Örgütlerde Psikolojik Kontrat İhlalleri ve Sinizm İlişkisi: 45 Yıldızlı Otel İşletmeleri Üzerine Bir Araştırma. 17. Ulusal Yönetim ve Organizasyon Kongresi, Eskişehir Osmangazi Üniversitesi İşletme Bölümü, Eskişehir, 688-692.

Wayne, S. J, Shore, L. M. ve Liden, R. C. (1997). Perceived Organizational Support and Leader-Member Exchange: a Social Exchange Perspective. Academy of Management Journal, 40(1), 82- 111.

Weisberg, J., ve Kirschenbaum, A. (1991). Employee Turnover Intentions: Implications From a National Sample. The International Journal of Human Resource Management, 2(3), 359-375.

Weisberg, J. (1994). Measuring Workers' Burnout and Intention to Leave. International Journal of Manpower, 15(1), 4-14.

Yapıcı, N. (2008). İşyerinde Sistematik Yıldırma (Mobbing), Algılanan Nedenleri ve İş Tatmini ile İşten Ayrılma Niyeti Üzerine Etkisi: Antalya İli Tarım Sektöründe Bir Araştırma. Akdeniz Üniversitesi Sosyal Bilimler Enstitüsü, Yayınlanmamış Yüksek Lisans Tezi, Antalya.

Zapf, D. ve Einarsen, S. (2005). Mobbing at Work: Escalated Conflicts in Organizations. İçinde S. Fox ve P. E. Spector (Ed.), Counterproductive work behavior: Investigations of actors and targets (ss. 237-270). Washington, DC, US: American Psychological Association. 